Psychology of Language and Communication 2009, Vol. 13, No. 1

DOI: $10.2478 /$ v10057-009-0002-9

\author{
JOLANTA RYTEL \\ Cardinal Stefan Wyszyński University, Warsaw
}

\title{
ARGUING TO PERSUADE AND ARGUING TO EXPLORE IN PRESCHOOLERS' NARRATIVE DISCOURSE
}

\begin{abstract}
The paper focuses on argumentation occurring in the process of co-constructing narrative text at the preschool age in the two types of situations: one where disagreement between the discourse participants occurs, and another where none of the discourse participants has opposed the speaker's position, in undisputed, non-conflict situations. The data come from a study of 162 children between ages four and seven. The children participated in the study as co-narrators (two children in the role of co-narrators), who constructed a text for a peer listener (a third child in the role of a listener). The analyzed material consisted of 93 narrative texts. The findings show that the argumentation refers to both dimensions of children's narration activity: the content introduced by discourse participants, i.e., the semantic dimension of the constructed text, and the process of constructing the text, i.e., the interactive dimension (who, when and how introduces any given information). However, in conflict situations the argumentation more often concerns the interactive dimension. On the other hand, in non-conflict situations, the argumentation more often concerns the semantic dimension of the discourse. Moreover, when the argumentation refers to the rules of interaction in the discourse, it is mostly characterized by a simple structure and is constructed individually. When the argumentation refers to the content which is introduced in the discourse, in the non conflict situations it is still mostly characterized by asimple and individually created structure, but in comparison to the conflict situations it is more often constructed jointly and results in the more compound structures. The analyses of argumentation in the two types of situation - conflict and non conflict ones - reveal that convincing, as the main goal of argumentation, can be realized in narrative discourse in different ways.
\end{abstract}

Key words: discourse, children's narratives, discourse interaction, argument structure

\section{Introduction}

Argumentation constitutes one of the most common forms of human interaction. Argumentation is associated with an attempt to convince another person (or ourselves) and to influence opinions or actions. Relatively rarely, it seems, we make

The material used in the analyses presented here was collected during the preparation for the author's doctoral dissertation entitled Argumentation in preschoolers' narrative discourse (under supervision of Professor Barbara Bokus), Faculty of Psychology, University of Warsaw, 2003. Address for correspondence: Jolanta Rytel, Cardinal Stefan Wyszyński University, Institute of Psychology, ul. Wóycickiego 1/3, 01-938 Warszawa, Poland. E-mail: j.rytel@uksw.edu.pl 
a statement only to provide a recipient with information about reality. More often, not only do we inform others about some facts, but also we aim at achieving something with the act of communication. "A need to change other people's convictions, attitudes and behaviors is one of the strongest human's inclinations and it almost always appears in two person interaction, even though they do not really intent to influence each other" (Grzelak, Nowak, 2001, p. 187). Referring to Bruner's distinction between two modes of thought (Bruner, 1986): a narrative and a paradigmatic one, the latter, which concerns thinking understood as "logic, scientific, abstract, explanatory or descriptive" (McCabe, 2005, p. 323) is expressed in argumentative or expository discourse. Argumentation can be treated as the activity of producing arguments that support or refute a position taken on a given matter (in favor or against). It can relate to positions on a state of things or facts, but also acts or courses of action. The aim of argumentation is to convince somebody (ourselves or another) about the possibility of accepting (pro-argumentation) or rejecting (contra-argumentation) the position taken on a particular matter. The above definition stresses the processual aspect of argumentation and allows for emphasizing its purposive and interactive character. Argumentation - by introducing the arguments that support or refute a position taken on a given matter - is an attempt to convince somebody to take the same position. It aims at achieving the acceptance of the position. Moreover, argumentation is interactive. It is directed towards the person that we attempt to persuade, the acceptance of which we want to achieve. It can be a partner of interaction; it can also be the same person, who provides the arguments. Finally, argumentation is also an act of providing the arguments. In other words, when we speak of argumentation in its processual aspect, we mean the act of arguing. However, when we refer to the outcome of this process - we regard argumentation as the result of the process of arguing.

Even though argumentative discourse appears to be significantly different from narration, argumentation may occur in both: in the course of various activities that children are involved in, as well as in the course of various discourses they carry on. Both types of discourse - narrative and argumentative - may intertwine (Berman \& Katzenberger, 2004; Berman \& Nir-Sagiv, 2007; Brumark, 2008). The research on the relation between both types of discourse concerns, most often, legal argumentation and it concentrates on analyzing the situations when the narrative is used to support a claim (Voss \& Van Dyke, 2001). Even though many empirical results show that argumentation skills develop early in life (as early as among 3-4 year old children) few studies address the problem of argumentation in the different types of discourse among children. In this article we focus on argumentation occurring in the process of co-constructing narrative text at the preschool age in the two types of situations: one where disagreement between the discourse participants occurs, and the other where none of the discourse participants has opposed the speaker's position, in undisputed, nonconflict situations. 


\section{Research questions}

We assume that in the two types of situations, conflict and non-conflict, argumentation can concern both the content introduced by discourse participants, i.e., the semantic dimension of the constructed text, and the process of constructing the text, i.e., the interactive dimension (who, when and how introduces any given information). Moreover, in both types of situations, we analyze the structure of the argumentation as well as the process of its creation. We do so, seeking the answers to the following research questions:

1. To which dimension of the narration activity is children's argumentation more often related in conflict and non-conflict situations?

2. What is the structure of argumentation and how do the discourse participants create it in both types of situation?

\section{Subjects and material}

A total of 162 children between 4 and 7 years took part in the research (54 children at each of three age levels: 4;3-4;9, 5;3-5;9 and 6;3-6;9). Of these, 108 children (36 at each level) recounted to peer listeners the adventure of film heroes. Fifty-four children (18 at each age level) played the role of listeners who could ask questions when they did not understand what had been said.

The children who participated in the study as co-narrators (two children in the role of co-narrator) constructed together a text for the other peer listeners (one child in role of listener). In all cases the gender of the co-narrators was the same. In nearly half of the cases the listeners were of the same gender as the co-narrators and in the remaining cases were of the opposite gender.

The film entitled „Pear story” [used by Chafe and his co-workers (see Kurcz, 1987) in cross-cultural studies on the role of internal schemas in text construction] was seen by the narrators (but not by the listeners). The film starts with a scene where a man is picking pears from a pear-tree in a garden. A boy on a bicycle passes by. He looks all around and takes one basket of the pears. Following that, there is a bicycle accident and three other boys help the main character. As a reward they get three pears, one for each of them. At the end of the film they pass by in front of the gardener and he observes them eating the pears. The film lasts about six minutes and there is no speech (dialogues between characters), but only a nonverbal soundtrack with sound effects.

The investigation had two phases: the preparatory phase, when the co-narrators planned the narrative discourse, and the narration phase proper, when they produced the narrative discourse. According to the research design, the second phase was followed by a preparation of a picture book about the narrative heroes' adventure. The narrative discourse in both phases was recorded. The children's nonverbal behaviours were also registered on observational protocols. The material used in 
our analysis consisted of 93 narrative texts, 39 produced by two co-narrators in the preparatory phase and 54 produced in the narration phase proper. A total of 4463 child utterances in roles of narrators and listeners were analyzed.

\section{Method of analysis}

To answer the research questions, we identify two types of situations, in which the participants of the narrative discourse may use argumentation. The first one concerns the cases characterised by disagreement between the discourse participants. We consider these cases as a conflict situation, as one discourse participant here opposes the thing told or done by the other one (or to the way in which it is done). However, argumentation may also occur in situations, when neither of the discourse partners raises any objections. We call such cases non-conflict situations. Further, for both types of situations we categorize each case of argumentation in relation to its subject. That is, we indicate if argumentation concerns the content, introduced by the narration participants (i.e., it refers to the semantic dimension); or if argumentation concerns the way, in which the narration text is being created (i.e., this refers to the interactive dimension: who, when and how introduces any given information).

Finally, the structure of argumentation is categorized in relation to the following four types of argumentation structures (see: van Eemeren \& Grootendorst, 1984):

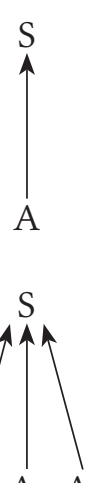

$\mathrm{A}_{1} \mathrm{~A}_{2} \mathrm{~A}_{3}$

\section{Single argumentation}

An argument (A) stands for a necessary, yet sufficient justification of the expressed statement (S), e.g.: $\mathrm{N}_{2}$ (Girl, 5;7): Pan myślat, że to oni ukradli (S), bo jedli gruszki (A) - 'A man thought they had stolen them (S), because they were eating the pears (A)'.

\section{Multiple argumentation}

Each argument $\left(A_{1}, A_{2}, A_{3}\right)$ is a sufficient justification for the expressed statement (S), e.g. $\mathrm{N}_{2}$ (Boy, 6;4): I on chyba im dat te trzy gruszki (S), bo mieli w ręku $\left(\mathrm{A}_{1}\right)$ i sobie jedli $\left(\mathrm{A}_{2}\right)$-'And I guess he had give them these three pears (S), because they had them in their hands $\left(\mathrm{A}_{1}\right)$ and they ate them right away $\left(\mathrm{A}_{2}\right)$ '.

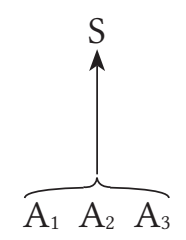

\section{Coordinative compound argumentation}

Each argument $\left(\mathrm{A}_{1}, \mathrm{~A}_{2}, \mathrm{~A}_{3}\right)$ is equivalent and necessary; they jointly form the sufficient justification for the expressed statement (S), e.g. $\mathrm{N}_{1}$ (Girl, 5;4): $\mathrm{N}_{1}$ (Dz. 5;4): A potem pan zszedt $z$ tego drzewa, jak nazbierat $i$, $i$ chciat wrzucić do kosza jak tamte gruszki; (włącza się kontynuator dyskursu) $\mathrm{N}_{2}$ (Dz. 5;6): I patrzy nie ma kosza ( $\mathrm{A}_{1}$ ); (po czym inicjator dyskursu opowiada dalej) $\mathrm{N}_{1}$ : I myśli sobie: tu szli takie chtopcy $i$ wtedy, że oni zabrali mu kosz(S) - 'And then he 
went down, off the tree, when he picked all the pears and wanted to put them into the basket, just as before; (the continuator of the discourse enters the discourse) $\mathrm{N}_{2}$ (Girl, 5;6): And he sees, there is no basket $\left(\mathrm{A}_{1}\right)$; (the initiator of the discourse continues) $\mathrm{N}_{1}$ : And he thinks: there were boys walking and he saw that they have one pear in each hand $\left(\mathrm{A}_{2}\right)$, and he thought then that they had taken his basket (S)'.

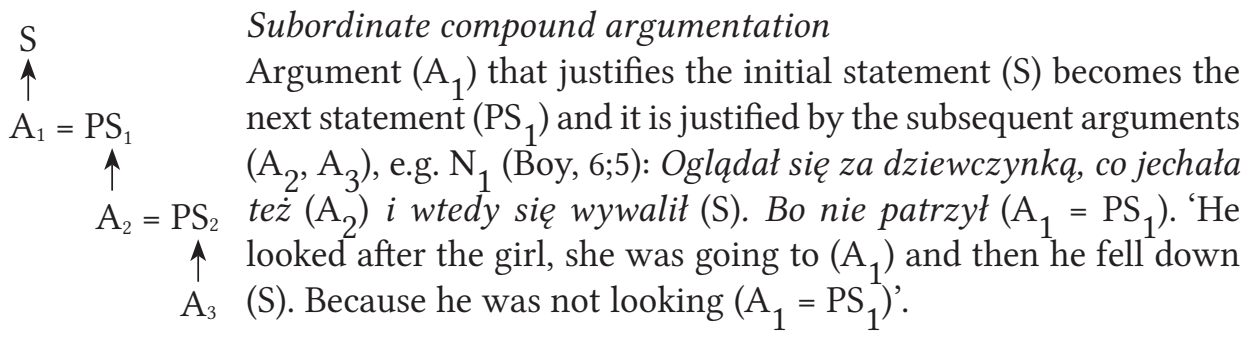

The first, basic structure of argumentation (statement + argument) we labelled as simple argumentation. All the other forms, and any of their modifications, we labelled as compound argumentation.

Moreover, we always identify if the statement and argument (or arguments) appear in the utterances of one discourse participants, or rather if it is constructed jointly by the children. Below, we present examples of various ways in which the argumentation is constructed, in relation to the content introduced:

Jointly, by all discourse participants (both narrators and the listener)

$\begin{array}{ll}\mathrm{N}_{1} \text { (Boy 4;8) } & \mathrm{N}_{2} \text { (Boy 4;8) L (Girl 4;4) } \\ & \text { Przechodzili sobie i on } \\ & \text { zobaczyt, że oni jedzq } \\ & \text { sobie gruszki i pomyślat } \\ & \text { sobie: skąd oni wzięli? } \\ \text { 'They were passing by } \\ \text { and he saw they were } \\ \text { eating these pears and } \\ \text { he thought: where did } \\ \text { they get them from?' }\end{array}$

No. A on im przecież

nie dat

'Yeah. Cause he didn't

give these to them' 
No wtaśnie, bo oni tego koszyka wzięli, prawda? 'Yeah right, cause they took them from this basket, right?'

No

'Yeah'

Tak. I oni...

'Yes. And they...'

I on, $i$ on o tym nie wiedziat, prawda?

'And he, he didn't know that, right?'

Tak. I myślat sobie, $i$ myślat, że oni mu chyba ukradli

'Yes. He thought, and he thought they were maybe stolen'

Or individually, by one narrator

$\mathrm{N}_{1}$ (Boy 6;3)

A ja pamiętam, że ten facet pomyślat, że to oni ukradli mu gruszki

'And I remember, this guy, he thought they had stolen these pears from him'

No

'Yeah'

Bo jak on zrywat gruszki, to on nie widziat, jak ten chtopiec na rowerze zabrat mu caty kosz

'Cause when he was picking up the pears, he didn't see how this boy on the bicycle took the whole basket from him'

$\mathrm{N}_{2}$ (Boy 6;6) 
Table 1. The argumentation structures related to the semantic and interactive aspect of narration, in conflict situations (absolute frequencies and relative in \%)

\begin{tabular}{lcccccccc}
\hline \multirow{2}{*}{ Dimension } & \multicolumn{4}{c}{ Age of children } & \multicolumn{2}{c}{ Total } \\
& 4-year-olds & \multicolumn{2}{c}{ 5-year-olds } & \multicolumn{2}{c}{ 6-year-olds } & \multicolumn{2}{c}{ \% } \\
& $\mathrm{n}$ & $\%$ & $\mathrm{n}$ & $\%$ & $\mathrm{n}$ & $\%$ & $\mathrm{n}$ & $\%$ \\
\hline Semantic & 3 & 18,8 & 7 & 28,0 & 15 & 39,5 & 25 & 31,6 \\
Interactive & 13 & 81,2 & 18 & 72,0 & 23 & 60,5 & 54 & 68,4 \\
Total & 16 & 100,0 & 15 & 100,0 & 38 & 100,0 & 79 & 100,0 \\
\hline
\end{tabular}

\section{Results}

In the analyzed material, 168 argumentation structures are identified. In both types of situations, the discourse participants use argumentation with almost equal frequency: 79 argumentation structures (47,0\%) appear in the conflict situations, whereas $89(53,0 \%)$ - in the non-conflict ones. In Table 1, we present the frequencies of the argumentation structures that appear in the conflict situation in each age group, divided by the dimension of the narration activity.

In the conflict situations, argumentation refers to the process of story creation more often then to the semantic dimension. Does it refer to the interactive dimension more often also in the non-conflict situations? The question can be answered based on the frequencies of the argumentation structures related to both dimensions that appear in the non-conflict situation in each age group. We present them in Table 2 below.

The frequencies for the non-conflict situations give an inverse ratio. The argumentation appears more frequently in relation to the semantic dimension. For a clearer picture, we summarize the data in Table 3. It presents the frequencies of argumentation structures, related to the semantic and interactive dimension, in conflict and non-conflict situations, for all children.

Table 2. The argumentation structures related to the semantic and interactive dimension, in non-conflict situations (absolute frequencies and relative in \%)

\begin{tabular}{lcccccccc}
\hline \multirow{2}{*}{ Dimension } & \multicolumn{4}{c}{ Age of children } & \multicolumn{2}{c}{ 6-year-olds } & \multicolumn{2}{c}{ Total } \\
& \multicolumn{2}{c}{ 4-year-olds } & \multicolumn{2}{c}{ 5-year-olds } & \multicolumn{2}{c}{-year } \\
& $\mathrm{n}$ & $\%$ & $\mathrm{n}$ & $\%$ & $\mathrm{n}$ & $\%$ & $\mathrm{n}$ & $\%$ \\
\hline Semantic & 14 & 82,4 & 21 & 72,4 & 26 & 60,5 & 61 & 68,5 \\
Interactive & 3 & 17,6 & 8 & 27,6 & 17 & 39,5 & 28 & 31,5 \\
Total & 17 & 100,0 & 29 & 100,0 & 43 & 100,0 & 89 & 100,0 \\
\hline
\end{tabular}


Table 3. The argumentation structures related to the semantic and interactive dimension in conflict and non-conflict situations (absolute frequencies and relative in \%)

\begin{tabular}{lcccccc}
\hline \multirow{2}{*}{ Dimension } & \multicolumn{2}{c}{ Conflict situations } & \multicolumn{2}{c}{$\begin{array}{c}\text { Non-conflict } \\
\text { situations }\end{array}$} & \multicolumn{2}{c}{ Total } \\
& $\mathrm{n}$ & $\%$ & $\mathrm{n}$ & $\%$ & $\mathrm{n}$ & $\%$ \\
\hline Semantic & 25 & 31,6 & 61 & 68,5 & 86 & 51,2 \\
Interactive & 54 & 68,4 & 28 & 31,5 & 82 & 48,8 \\
Total & 79 & 100,0 & 89 & 100,0 & 168 & 100,0 \\
\hline
\end{tabular}

Table 4. Simple and compound argumentation related to the semantic dimension (absolute frequencies and relative in $\%$ )

\begin{tabular}{lcccccccc}
\hline \multirow{3}{*}{ Argumentation } & \multicolumn{4}{c}{ Age of children } & \multicolumn{3}{c}{ Total } \\
& \multicolumn{2}{c}{ 4-year-olds } & \multicolumn{2}{c}{ 5-year-olds } & \multicolumn{2}{c}{ 6-year-olds } & \multicolumn{2}{c}{ \% } \\
& $\mathrm{n}$ & \multicolumn{1}{c}{$\mathrm{n}$} & $\boldsymbol{\%}$ & $\mathrm{n}$ & $\%$ & $\mathrm{n}$ & $\%$ \\
\hline Simple & 9 & 52,9 & 20 & 71,4 & 22 & 53,7 & 51 & 59,3 \\
Compound & 8 & 47,1 & 8 & 28,6 & 19 & 46,3 & 35 & 40,7 \\
Total & 17 & 100,0 & 28 & 100,0 & 41 & 100,0 & 86 & 100,0 \\
\hline
\end{tabular}

Table 5. Simple and compound argumentation related to the semantic dimension, in conflict and non-conflict situations (absolute frequencies and relative in \%)

\begin{tabular}{lcccccc}
\hline \multirow{2}{*}{ Dimension } & \multicolumn{2}{c}{ Conflict situations } & \multicolumn{2}{c}{$\begin{array}{c}\text { Non-conflict } \\
\text { situations }\end{array}$} & \multicolumn{2}{c}{ Total } \\
& $\mathrm{n}$ & $\%$ & $\mathrm{n}$ & $\%$ & $\mathrm{n}$ & $\%$ \\
\hline Simple & 19 & 76,0 & 32 & 52,5 & 51 & 59,3 \\
Compound & 6 & 24,0 & 29 & 47,5 & 35 & 40,7 \\
Total & 25 & 100,0 & 61 & 100,0 & 86 & 100,0 \\
\hline
\end{tabular}

Table 6. The argumentation related to the semantic dimension, constructed individually or jointly (absolute frequencies and relative in \%)

\begin{tabular}{lcccccccc}
\hline \multirow{3}{*}{ Argumentation } & \multicolumn{4}{c}{ Age of children } & \multicolumn{3}{c}{ Total } \\
& \multicolumn{2}{c}{ 4-year-olds } & \multicolumn{2}{c}{ 5-year-olds } & \multicolumn{2}{c}{ 6-year-olds } & \multicolumn{2}{c}{ \% } \\
& $\mathrm{n}$ & $\%$ & $\mathrm{n}$ & $\%$ & $\mathrm{n}$ & $\%$ & $\mathrm{n}$ & $\%$ \\
\hline Individually & 11 & 64,7 & 21 & 75,0 & 37 & 90,2 & 69 & 80,2 \\
Jointly & 6 & 35,3 & 7 & 25,0 & 4 & 9,8 & 17 & 19,8 \\
Total & 17 & 100,0 & 28 & 100,0 & 41 & 100,0 & 86 & 100,0 \\
\hline
\end{tabular}


In the conflict situations, the argumentation refers to the process of story creation almost as frequently as it does to the content, which is introduced by the discourse participants, in the non-conflict situations. The argumentation related to the semantic dimension appears in the conflict situations less often; equally rarely does argumentation on the interactive dimension appear in the non-conflict cases.

When analyzing the prevalence of argumentation structures, related to the story content, in both, conflict and non conflict situations (25 versus 61 occurrences), we find that the difference between the proportions (respectively $29,1 \%$ and $70,9 \%$ ) is significant, indicating more occurrences in the non-conflict cases $(z=7,975 ; p<$ $0,005)$. The argumentation refers to the semantic dimension over twice more often here. Similar results are found for the argumentation structures related to interactive dimension, in conflict and non conflict cases (54 versus 28 occurrences). This type of argumentation appears more frequently in the conflict cases $(65,9 \%)$ than in the non-conflict ones $(34,1 \%)$. Again, the result is statistically significant $(z=5,863 ; p$ $<0,005)$ and the difference is almost twofold.

\section{Story content: The structure of the argumentation and the process of its constructing in the conflict and non-conflict situations}

Among the 168 argumentation structures, 86 (51,2\%) refer to the content which is introduced by the discourse participants, that is, to the semantic dimension. Table 4 depicts how many of these are regarded as simple or compound, for all age groups in the study.

In relation to the semantic dimension, children in all age groups apply the basic structure of argumentation - that is, simple argumentation (statement + argument). Does the simple structure of argumentation occur more often regardless of the type of situation?

In Table 5, we present the frequencies of simple and compound argumentation structures, constructed by the children in conflict and non-conflict situations.

Even though, in the conflict as well as non-conflict situations simple argumentation is more common, this structure of argumentation occurs more frequently in the non-conflict cases, rather than non-conflict ones (32 versus 19 occurrences). The test of proportions shows that this difference is statistically significant $(62,7 \%$ versus $37,3 \%, \mathrm{z}=3,671 ; \mathrm{p}<0,005)$. Moreover, the same holds for the compound argumentation. The compound structures also occur more often in the non-conflict situations: 29 times against 6 times in the conflict situations. The difference is statistically significant (82,9\% versus $17,1 \%, \mathrm{z}=8,498 ; \mathrm{p}<0,005)$.

In the majority of cases the statement as well as the argument appear in the utterances of one discourse participant: an initiator, a partner continuing discourse, or a listener. Less frequently the argumentation structure was constructed by the children in a joint manner. In table 6 , we present the counts of argumentation structures that refer to the semantic dimension, which are constructed jointly by the discourse participants or just individually by one of them. 
Table 7. The argumentation related to the semantic dimension, constructed individually or jointly in conflict and non-conflict situations (absolute frequencies and relative in \%)

\begin{tabular}{lcccccc}
\hline \multirow{2}{*}{ Argumentation } & \multicolumn{2}{c}{ Conflict situations } & \multicolumn{2}{c}{$\begin{array}{c}\text { Non-conflict } \\
\text { situations }\end{array}$} & \multicolumn{2}{c}{ Total } \\
& $\mathrm{n}$ & $\%$ & $\mathrm{n}$ & $\%$ & $\mathrm{n}$ & $\%$ \\
\hline Individually & 23 & 92,0 & 46 & 75,4 & 69 & 80,2 \\
Jointly & 2 & 8,0 & 15 & 24,6 & 17 & 19,8 \\
Total & 25 & 100,0 & 61 & 100,0 & 86 & 100,0 \\
\hline
\end{tabular}

Table 8. The argumentation simple and compound, related to the interactive dimension (absolute frequencies and relative in \%)

\begin{tabular}{lcccccccc}
\hline \multirow{3}{*}{ Argumentation } & \multicolumn{9}{c}{ Age of children } & \multicolumn{2}{c}{ Total } \\
& \multicolumn{2}{c}{ 4-year-olds } & \multicolumn{2}{c}{ 5-year-olds } & \multicolumn{2}{c}{ 6-year-olds } & \multicolumn{2}{c}{ \% } \\
& $\mathrm{n}$ & $\%$ & $\mathrm{n}$ & $\%$ & $\mathrm{n}$ & $\%$ & $\mathrm{n}$ & $\%$ \\
\hline Simple & 11 & 68,8 & 19 & 73,1 & 34 & 85,0 & 64 & 78,0 \\
Compound & 5 & 31,2 & 7 & 26,9 & 6 & 15,0 & 18 & 22,0 \\
Total & 16 & 100,0 & 26 & 100,0 & 40 & 100,0 & 82 & 100,0 \\
\hline
\end{tabular}

Table 9. The simple and compound argumentation related to the interactive dimension, in conflict and non-conflict situations (absolute frequencies and relative in \%)

\begin{tabular}{|c|c|c|c|c|c|c|}
\hline \multirow[t]{2}{*}{ Dimension } & \multicolumn{2}{|c|}{ Conflict situations } & \multicolumn{2}{|c|}{$\begin{array}{l}\text { Non conflict } \\
\text { situations }\end{array}$} & \multicolumn{2}{|c|}{ Total } \\
\hline & $\mathrm{n}$ & $\%$ & $\mathrm{n}$ & $\%$ & $\mathrm{n}$ & $\%$ \\
\hline Simple & 44 & 81,5 & 20 & 71,4 & 64 & 78,0 \\
\hline Compound & 10 & 18,5 & 8 & 28,5 & 18 & 22,0 \\
\hline Total & 54 & 100,0 & 28 & 100,0 & 82 & 100,0 \\
\hline
\end{tabular}

Table 10. The argumentation related to the interactive dimension - constructed individually or jointly (absolute frequencies and relative in \%)

\begin{tabular}{|c|c|c|c|c|c|c|c|c|}
\hline \multirow{3}{*}{ Argumentation } & \multicolumn{6}{|c|}{ Age of children } & \multirow{2}{*}{\multicolumn{2}{|c|}{ Total }} \\
\hline & \multicolumn{2}{|c|}{ 4-year-olds } & \multicolumn{2}{|c|}{ 5-year-olds } & \multicolumn{2}{|c|}{ 6-year-olds } & & \\
\hline & $\mathrm{n}$ & $\%$ & $\mathrm{n}$ & $\%$ & $\mathrm{n}$ & $\%$ & $\mathrm{n}$ & $\%$ \\
\hline Individually & 14 & 87,5 & 23 & 88,5 & 36 & 90,0 & 73 & 89,0 \\
\hline Jointly & 2 & 12,5 & 3 & 11,5 & 4 & 10,0 & 9 & 11,0 \\
\hline Total & 17 & 100,0 & 28 & 100,0 & 41 & 100,0 & 86 & 100,0 \\
\hline
\end{tabular}


Table 11. The argumentation related to the interactive dimension, constructed individually or jointly in conflict and non-conflict situations

\begin{tabular}{lcrrrrc}
\hline \multirow{2}{*}{ Argumentation } & \multicolumn{1}{c}{ Conflict situations } & \multicolumn{2}{c}{$\begin{array}{c}\text { Non conflict } \\
\text { situations }\end{array}$} & \multicolumn{2}{c}{ Total } \\
& \multicolumn{1}{c}{$\mathrm{n}$} & \multicolumn{1}{c}{$\%$} & \multicolumn{1}{c}{$\mathrm{n}$} & \multicolumn{1}{c}{$\%$} & $\mathrm{n}$ & $\%$ \\
\hline Individually & 50 & 92,6 & 23 & 82,1 & 73 & 89,0 \\
Jointly & 4 & 7,4 & 5 & 17,9 & 9 & 11,0 \\
Total & 54 & 100,0 & 28 & 100,0 & 82 & 100,0 \\
\hline
\end{tabular}

Subsequently, Table 7 shows the frequencies of argumentation structures which are constructed jointly or individually in the conflict and non-conflict situations. For both types of situations, the children more often construct argumentation individually. However, the individual argumentation occurs more frequently in the non-conflict situations (46 times) than in the conflict ones (23 times). The difference is statistically significant ( $66,7 \%$ versus $33,3 \%, z=5,659 ; p<0,005)$. We find the same result for the jointly constructed argumentations. This type of construction takes place more often in the non-conflict situation (15 occurrences) than in the conflict ones ( 2 occurrences). Again, the difference is statistically significant ( $88,2 \%$ versus $11,8 \%, \mathrm{z}=7,170 ; \mathrm{p}<0,005)$.

\section{The story telling process: the structure of argumentation and the process of its constructing in the conflict and non-conflict situations}

Among the 168 argumentation structures, 82 (48,8,\%) refer to the process of the story telling, that is, to the interactive dimension. Table 8 shows how many of these are simple and how many are compound, for all age groups in the study.

As to the interactive dimension, the simple argumentation structure is the dominant one. Table 9 conveys the frequencies of the single and compound argumentation structures for the conflict and non-conflict situations. For both types of situations, the simple argumentation prevails. Comparison, as to in which situation the simple argumentation occurs more often shows that it is more frequent in the conflict ones (44 cases) than in the non-conflict ones (20 cases). The ratio is statistically significant $(68,8 \%$ versus $32,2 \%, z==6,168 ; p<0,005)$. The distribution of the compound argumentation appears rather even: $55,6 \%$ of the compound argumentations appears in the conflict situations (10 cases) whereas $44,4 \%$ - in the non-conflict ones ( 8 cases). The ratio is not statistically significant $(z=0,950$; n.s.).

How was the argumentation, related to the interactive dimension, constructed? As we illustrate in table 10, the children in all the age groups more frequently constructed it individually. The joint process of construction appears very rarely.

Similarly (see Table 11), regardless of the type of situation (conflict or non-conflict) the argumentation was constructed individually in the majority of cases. The 
argumentation was created individually more often in the conflict situations (50 cases) than in the non-conflict ones (23 cases). The difference is statistically significant $(68,5 \%$ versus $31,5 \%, z=6,476 ; p<0,005)$. However, as to the jointly constructed argumentation, the difference was not significant (5 cases in the conflict situations and 4 cases in the non-conflict situations, $55,6 \%$ versus $44,4 \%, z=0,672$; n.s.).

\section{Discussion}

Constructing a narration text, in the course of monolog or dialog, occurs in the same manner as constructing any other text. As pointed out by Kurcz (2000/2005), it requires following two main rules: a rule of reality and a rule of cooperation. The rule of reality refers to the content of the communication, whereas the rule of cooperation concerns ways, in which the content is expressed and communicated. According to the first rule, the listener interprets the received content as reasonable and referring to possible realities. Based on that, the listener creates appropriate representations in his or her knowledge system and that allows for avoiding incorrect interpretation and solving the ambivalences. The second rule, the one of cooperation, regulates the process in which the discourse partners participate in constructing the discourse.

In the presented study, we analyze the narrative discourse, and occurring in its course argumentation, in such a form of interaction, in which three partners take part: two co-narrators and one listener. The task of the co-narrators required telling to the peer listener about the content of the watched movie. As a result they could jointly make the picture book illustrating the film. The text constructed in the course of the narrative discourse is the effect of co-operation of all interaction partners. Each participant creates his or her own representation of the watched events and presents it in the narration. Each of the narrators creates also his or her own representation of the means to perform the activity which they are involved in, namely, how to carry on the narration process itself. The process, in which the story is constructed by the peers, is the effect of children's interacting on two levels. They have to negotiate, accept and coordinate their interpretations of the film events. They also have to make decisions as to the way in which their activity is realized.

The findings show that the argumentation refers to both dimensions of children's narration activity. However, when there is disagreement between the discourse participants - in the conflict situations - it more often concerns the interactive dimension. On the other hand, in the non-conflict situations, the argumentation more often concerns the semantic dimension of the discourse. Moreover, when the argumentation refers to the rules of interaction in the discourse, it is mostly characterized by a simple structure and is constructed individually. When the argumentation refers to the content, which is introduced in the discourse, in the non-conflict situations it is still mostly characterized by a simple and individually 
created structure, but in comparison to the conflict situations it is more often constructed jointly and results in the more compound structures.

How to explain the above findings? We shall consider in greater detail the subjects of argumentation in both of the cases, as the argumentation process depends, at least to some extent, precisely on its subject. It also depends on the discourse participants' perceptions of the problem, which is solved by the means of argumentation (see Darnon, Doll, \& Butera, 2007). When the child constructs a story with a peer partner, both narrators can act as equal agents, as they both share similar competences and similar knowledge as to the task they carry out together. Such situation activates the child's experience of being a subject - an independent author of the actions (Shugar, 1989; Kofta, 1989). Their way in which a child shares the authorship with the partner, the realization of and the control over the task, can be all shaped freely in the course of the interaction. If disagreement between the discourse partners occurs (and apparently it does occur! see Rytel, 2006; Rytel, forthcoming) as to who (which of them) and how to tell the story - the disagreement concerns the viewpoints on the task realization and on the narrators' competences. It can be illustrated with the following examples:

$\mathrm{N}_{1}$ (Boy. 6;5)

Wtedy chtopaki pozbierali mu

i znaleźli mu te gruszki, pamiętasz?

'Then the boys were gathering and finding these pears for him, remember?'
$\mathrm{N}_{2}$ (Boy. 6;5)

Mhm

'Uhm'

Ale ja lepiej pamiętam, to ja będę mówit, dobra?

'But I remember better, so I will tell it, OK.?'

No.

'Yeah'

In the above example one narrator (the initiator of the discourse $-\mathrm{N}_{1}$ ), referring to his (higher) competence as to knowledge about the story content (ale ja lepiej pamiętam - 'but I remember better'), secures the control over the narration process for himself (to ja będę mówit, dobra? - 'so I will say, OK?'). In the next example, one narrator (the initiator of the discourse $-\mathrm{N}_{1}$ again) discredits the other narrator's suggestion on the joint story telling (No nie. Nie, będzie bez sensu, bo każda będzie co innego mówita - 'Well, no. No, it makes no sense, cause each of us will tell something different') and by this she wins the possibility to realize the story telling in the way she prefers. 
$\mathrm{N}_{1}$ (Girl 6;5)

Dobra, powiem, może powiemy

najpierw, $\dot{z} e$, ja powiem, $\dot{z} e$

'OK., first maybe we tell, first that I will tell that'

No nie. Nie, będzie bez sensu, bo każda będzie co innego mówita

'Well, no. No, it makes no sense, cause each of us will tell something different'
$\mathrm{N}_{2}($ Girl 6;7)
Może wszystko razem powiemy

'Maybe we will tell everything together'

As the discourse partners jointly construct the narration, the disagreement between them is a kind of a "stop sign" for the ongoing interaction. Not that the disagreement stops the interaction completely, but it suspends it. This suspension lasts until the partners, who express the opposing positions, reach the solution to the conflict. Then, the interaction may continue, in a direction indicated by the accepted settlement. So, when the disagreement as to the task realization appears, it requires an efficient and successful solution. The argumentation is used to persuade one interaction partner to accept the solution suggested by the other one.

In the undisputed, non-conflict situation the argued utterances of the discourse participants referred more often to the semantic aspects of the constructed text and mostly related to, besides the accidental events and the hero's actions, to the mental states or processes attributed to those heroes. Each of the narrators constructed his own representation of what happened to the hero, what were the motives of the hero's actions, what emotions he experienced (e.g., a ten pan zauważyt ten jeden kosz, a byty dwa kosze, to pomyślat: jakiś chtopaki zabraty, no to wtedy, to zdenerwowat sie - 'and this guy noticed this one basket, and there had been two baskets, and he thought: some kids had taken it, and so, so he got angry' /Boy 4;7/) and most of all: what the hero thought (e.g., zobaczyt, że nie ma jednego koszyka, a przechodzili tedy chlopcy, co mieli gruszki i on sobie pomyślat, że to oni właśnie zabrali gruszki - 'He saw there was one basket missing, and they were boys passing by, they had pears and he thought they had taken the pears' /Girl 6;4/) (Rytel, 2005). It is not an easy task to create a commonly shared interpretation, because internal states, similarly to the motives of heroes' actions, are unequivocal, nontransparent for perception. The narrators, when presenting the events from the perspective of the hero whom they describe, relate to states of things which by nature are not certain or necessary, but only possible or probable. Sometimes the narrators are not totally certain what has happened in the story, as for instance in the following example: 
$\mathrm{N}_{1}$ (Boy 5;5)

$\mathrm{N}_{2}$ (Boy 5;9)

Ten chtopak jechat. I ten, no, ten chtopak ukradt gruszki. Nie wiadomo, czy ukradt, czy pomagat

'This boy was cycling. And he, well, this boy, he stole the pears. It's not sure, if he stole or if he helped'

Mhm

'Mhm'

No i jeszcze było to, jak ten pan się tak fajnie zdziwit, że, że nie miat drugich gruszek, tylko miat to, wiesz 'And it was too, how this man, he was surprised so funny, that, that he didn't have these other pears, but he had this, you know'

Co?

'What?'

To puste pudto

'This empty box'

No. Nie wiadomo

'Yeah. One doesn't know'

On ukradt, bo pan nie widziat, jak on jechat na rowerze i tak się on rozgladat

'He stole, cause the man didn't see, how he was cycling and looking round'

No

'Yeah'

To może ukradt

'So maybe he stole'

Tak

'Yes'

In some situations, the lack of certainty as to the interpretation is attributed to the hero (I myślat sobie, i myślat, że oni mu chyba ukradli - 'He thought, and he thought they were maybe stolen'). In such cases, it is not a conflict of interests, in which the discourse partners need to find a solution in the situation of various opinions on the task realization. Rather, it is a problematic case, the solution to which involves all partners' knowledge and requires them to consult and negotiate a variety of possible interpretations. Thus, such a situation generates a need to justify each offered inter- 
pretation. After all, the discourse partner can have a different opinion on what "really" has happened in the story."This need to verify one's own perspective in coordination with other perspectives structures the process of interpersonal negotiations in ways that can promote cognitive growth" (Bearison, 1986, p. 136). Many researchers refer to this kind of situation as to a "socio-cognitive conflict" (Doise \& Mugny, 1984; Mugny, De Paolis, \& Carugati, 1984). For these authors, socio-cognitive conflict can be a key for cognitive growth, elaborated reasoning strategies, epistemic curiosity and the quality of reasoning or learning (see for review: Buchs, Butera, Mugny, \& Darnon, 2004). Most of these studies, however, concentrate on the effect the interaction has on the subsequent individual performance. The joint construction of knowledge is not the main focus in any of them.

The above studies show that the situation, in which children participate in the narrative discourse with a peer, gives them an opportunity to practice and develop their skills, in relation to two aspects of their narrative activity. Firstly, as children participate in the process of story-telling (interactive dimension of the narration), they get engaged in presenting and arguing for the preferred ways of realizing this task. In these cases, the discourse is rather disputable, characterized by disagreement and a rather individualized decision-making. Secondly, in relation to the content, which is introduced by each discourse participant (semantic dimension) from his or her own perspective, children get engaged into arguing for their viewpoints, as the viewpoints relate to the states and processes that can be only inferred and not directly observed. In this case, their discourse resembles the one distinguished along with two other types by Mercer (1996), namely, exploratory talk. Mercer, based on the conversation analyses of children aged 5-12 working in pairs or small groups on computer-based activities, identified three distinctive ways of talking and thinking. The exploratory talk is characterized as follows: „Exploratory talk occurs when partners engage critically but constructively with each other's ideas. Statements and suggestions are offered for joint consideration. These may be challenged and counter-challenged, but challenges are justified and alternative hypotheses are offered. Compared with the other two types, in exploratory talk knowledge is made more publicity accountable and reasoning is more visible in the talk. Progress then emerges from the eventual joint agreement reached" (Mercer, 1996, p. 369). In exploratory talk, the goal is to enhance understanding of an issue, not to win a debate.

The analyses of argumentation in the two types of situation - conflict and non-conflict ones - reveals that convincing, as the main goal of argumentation, can be realized in narrative discourse in different ways. First, when there is a conflict situation and the aim is to convince the partner to accept the preferred way of proceeding, the argumentation is constructed individually and has a simple structure. When the opposing position of the partner appears, it clearly signals the lack of agreement. The discourse participant, arguing for his or her own opinion, tries to convince the partner to accept it and consequently to reconcile the opposing viewpoints. In such a situation, the convincing is to a major extent directed toward 
making the partner take or abandon some actions.

The narrators referred to the argumentation also in the non-conflict situations. The non-conflict type of situations is particularly important as it indicates that the nature of argumentation is different here. It rather has the form of considerations about various possible accounts of the events; it is open for other discourse participants' argumentation and aims at reaching the most likely interpretation of what has happened. In such cases, it is not the interaction between the partners that is the source of argumentation, but rather the cognitive nature of the problem. The argumentation here is the means to test various, potentially contradictory viewpoints of narrators as to the different versions of the events. Consequently, the argumentation is constructed jointly more frequently here and its structure is more compound. The co-narrator, and sometimes also the listener, participated in the argumentation and jointly constructed the interpretation of the events. Convincing, in such cases, is not really the way of making the partner accept any given position. It is rather the consideration of the possibility to accept it in the process of argumentation. In our opinion, such unequivocal, problematic situations, in which a child has an opportunity to act as a researcher, who explores various solutions and discusses with others the arguments for or against accepting them, are crucial for the development of critical thinking.

\section{References}

Bearison, D., J. (1986). Transactional cognition in context: New model of social understanding. In D. J. Bearison \& H. Zimiles (Eds.), Thought and emotion: Development perspectives (pp. 129-146). Hillsdale: Erlbaum.

Berman, R. A., Katzenberger, I. (2004). Form and function in introducing narrative and expository texts: A developmental perspective. Discourse Processes, 38 (1), 57-94.

Berman, R. A., Nir-Sagiv, B. (2007). Comparing narrative and expository text construction across adolescence: A developmental paradox. Discourse Processes, 43 (2), 79-120.

Brumark, A. (2008). „Eat your hamburger!” - „No, I don't want to!” Argumentation and argumentative development in the context of dinner conversation in twenty Swedish families. Argumentation, 22, 251-271.

Bruner, J. (1986). Actual minds, possible words. Cambridge: Harvard University Press.

Buchs, C., Butera, F., Mugny, G., Darnon, C. (2004). Conflict elaboration and cognitive outcomes. Theory Into Practice, 45, 23-30.

Darnon, C., Doll, S., Butera, F. (2007). Dealing with a disagreeing partner: Relational and epistemic conflict elaboration. European fournal Of Psychology of Education, 22, 227-242.

Doise, W., Mugny, G. (1984). The social development of intellect. Oxford: Pergamon Press. 
van Eemeren, F. H., Grootendorst, R. (1984). Speech acts in argumentative disscussion. Dordrecht - Holland: Foris.

Grzelak, J. Ł., Nowak, A. (2001). Wpływ społeczny (Social influence). In J. Strelau (Ed.), Psychologia (Psychology) Vol. 3: Jednostka w spoteczeństwie i elementy psychologii stosowanej (Individual in the society and elements of applied psychology) (pp. 197-204). Gdańsk: Gdańskie Wydawnictwo Psychologiczne.

Kofta, M. (1989). Orientacja podmiotowa: Zarys modelu (Subjective orientation: The outline of a model). In A. Gurycka (Ed.), Podmiotowość w wychowawczych doświadczeniach dzieci i młodzieży (Subjectivity in educational experiences of children and adolescents), Vol.1: M. Kofta (Ed.), Wychowanek jako podmiot działań (Pupil as agent of actions) (pp. 65-93). Warszawa: Wydawnictwa UW.

Kurcz, I. (2000/2005). Psychologia języka i komunikacji (Psychology of language and communication). Warszawa: Wydawnictwo Naukowe „Scholar”.

McCabe, A. (2005). Zdania w połączeniach - tekst i dyskurs (Sentences in connections - Text and discourse). In J. Berko Gleason \& N. Bernstein Ratner (Ed.), Psycholingwistyka (Psycholinguistics) (pp. 299-332). Gdańsk: Gdańskie Wydawnictwo Psychologiczne.

Mercer, N. (1996). The quality of talk in children's collaborative activity in the classroom. Learning and Instruction, 6 (4), 359-377.

Mugny, G., De Paolis, P., Carugati, F. (1984). Social regulations in cognitive development. In W. Doise \& A. Palmonari (Eds.), Social interaction in individual development (pp. 127-146). Cambridge: Cambridge University Press.

Rytel, J. (2005). Is disagreement necessary? Argumentation in preschoolers' narrative discourse. In B. Bokus (Ed.), Studies in the psychology of child language. In honor of Grace Wales Shugar (pp. 313-327). Warszawa: Matrix.

Rytel, J. (2006). Disagreement in preschoolers' narrative discourse. Psychology of Languageand Communication, 10 (1), 21-44.

Rytel, J. (fothcoming). Monolog, dialog, polifonia - pragmatyka narracji dziecięcej (Monologue, dialog, polyphony - pragmatics of childrens' narration). In: B. Janusz, K. Gdowska \& B. de Barbaro (Eds.), Narracja: teoria i praktyka (Narration: theory and practice) (pp. 267-286). Kraków: Wydawnictwa Uniwersytetu Jagiellońskiego.

Shugar, G. W. (1989). Małe dziecko w sytuacji dwupodmiotowej: Jak powstaje i na czym polega struktura Wspólne Działanie? (Young child in a dual-agentive situation. What is the joint action structure and how does it emerge?). In A. Gurycka (Ed.), Podmiotowość w wychowawczych doświadczeniach dzieci i młodzieży, (Subjectivity in educational experiences of children and adolescents) Vol. 1: M. Kofta (Ed.), Wychowanek jako podmiot działań (Pupil as agent of actions) (pp. 65-93). Warszawa: Wydawnictwa Uniwersytetu Warszawskiego.

Voss, J. F., Van Dyke, J. A. (2001). Narrative structure, information certainty, emotional content, and gender as factors in a pseudo jury decision-making task. Discourse Processes, 32 (2/3), 215-243. 